\title{
Integrin $\alpha 6 \beta 4$ in Colorectal Cancer: Expression, Regulation, Functional Alterations and Use as a Biomarker
}

\author{
Jean-François Beaulieu 1,2 \\ 1 Laboratory of Intestinal Physiopathology, Faculty of Medicine and Health Sciences, Universite de \\ Sherbrooke, Sherbrooke, QC J1H 5N4, Canada; Jean-Francois.Beaulieu@USherbrooke.ca; \\ Tel.: +1-819-821-8000 (ext. 75269) \\ 2 Centre de Recherche du Centre Hospitalier Universitaire de Sherbrooke, Sherbrooke, QC J1H 5N4, Canada \\ Received: 6 December 2019; Accepted: 19 December 2019; Published: 21 December 2019

\begin{abstract}
Integrin $\alpha 6 \beta 4$ is one of the main laminin receptors and is primarily expressed by epithelial cells as an active component of hemidesmosomes. In this article, after a brief summary about integrins in the gut epithelium in general, I review the knowledge and clinical potential of this receptor in human colorectal cancer (CRC) cells. Most CRC cells overexpress both $\alpha 6$ and $\beta 4$ subunits, in situ in primary tumours as well as in established CRC cell lines. The mechanisms that lead to overexpression have not yet been elucidated but clearly involve specific transcription factors such as MYC. From a functional point of view, one key element affecting CRC cell behaviour is the relocalization of $\alpha 6 \beta 4$ to the actin cytoskeleton, favouring a more migratory and anoikis-resistant phenotype. Another major element is its expression under various molecular forms that have the distinct ability to interact with ligands $(\alpha 6 \beta 4 \pm \mathrm{ctd}$ ) or to promote pro- or anti-proliferative properties ( $\alpha 6 \mathrm{~A} \beta 4$ vs. $\alpha 6 \mathrm{~B} \beta 4)$. The integrin $\alpha 6 \beta 4$ is thus involved in most steps susceptible to participation with CRC progression. The potential clinical significance of this integrin has begun to be investigated and recent studies have shown that ITGA6 and ITGB4 can be useful biomarkers for CRC early detection in a non-invasive assay and as a prognostic factor, respectively.
\end{abstract}

Keywords: colorectal cancer; integrin $\alpha 6 \beta 4$; ITGA6; ITGB4; alternative splicing; expression; function; biomarker

\section{Introduction}

Epithelial cells lie and attach to the basement membrane, a specialized network of extracellular matrix molecules that comprise specific collagens, proteoglycans and exclusive glycoproteins such as laminins as well as non-exclusive ones such as fibronectins. Cell adhesion is mediated by membrane receptors specific for these glycoproteins. In the intestine, there are a number of these receptors that have been identified for epithelial cells including dystroglycan and the 37/67 kDa laminin receptor [1] as well as many that belong to the integrin family [2,3]. Integrins are transmembrane $\alpha \beta$ heterodimers that function as bidirectional signal transduction mediators acting as mechanosensors and participating in the regulation of main cell functions such as adhesion, migration, proliferation, survival and differentiation [4,5]. The gut epithelium expresses a wide variety of integrins as well as their corresponding ligands. Figure 1 illustrates the various heterodimers identified and their extracellular ligands. 


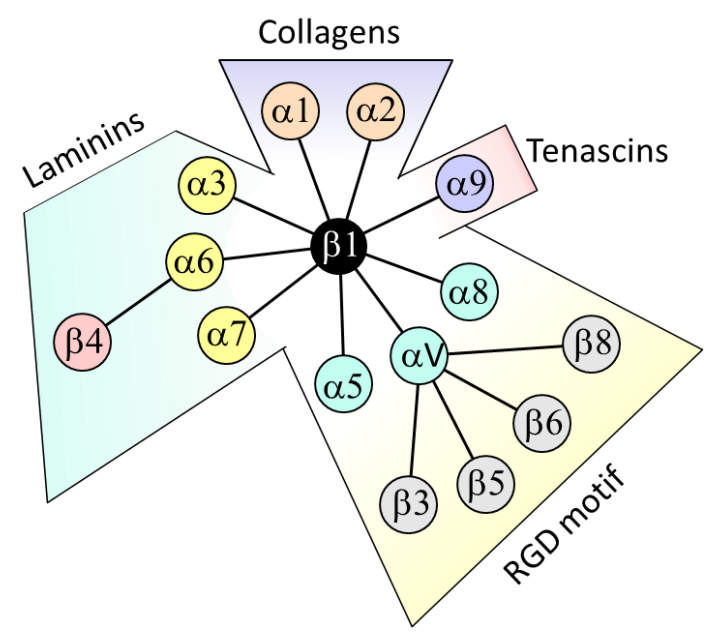

Figure 1. Integrins expressed in intestinal epithelial cells under normal or pathologic conditions. Integrins are classified according to their preferential ligands: collagens for $\alpha 1 / \alpha 2$ coupled to $\beta 1$, laminins for $\alpha 3 / \alpha 6 / \alpha 7$ coupled to $\beta 1$ or $\beta 4$, tenascin for $\alpha 9 \beta 1$ and RGD-containing ligands (fibronectin, osteopontin and vitronectin) for $\alpha 5 / \alpha 8$ coupled to $\beta 1$ and $\alpha \mathrm{V}$ coupled to $\beta 1 / \beta 3 / \beta 5 / \beta 6 / \beta 8$.

It is noteworthy that while some of these integrins are mostly associated with the differentiated state in the intestinal epithelium cells such as $\alpha 3 \beta 1$ and $\alpha 7 \beta 1$, many are predominantly expressed by the proliferative cells at the base of the epithelial cells of the crypts in both the small and large intestines $[2,3,6]$ and, more importantly in the context of this review, in primary and/or metastatic colorectal cancer (CRC) cells. This has been well documented recently for the $\alpha 1 \beta 1$ integrin, a collagen receptor. While exclusively expressed in the proliferative compartment in the normal colon, $\alpha 1 \beta 1$ was found to be overexpressed in CRC primary tumour and cell lines [7,8] and knockdown of $\alpha 1$ subunit expression resulted in the reduction of cell proliferation and tumour growth [9]. Integrin $\alpha 9 \beta 1$ is another interesting case. Expressed in the proliferative cells in the normal gut at the fetal stage but not in the adult, its resurgence in CRC cells both in primary tumours and in vitro is indicative of an oncofetal pattern of expression [10,11]. Two of the RGD-dependent integrins, $\alpha 5 \beta 1$ and $\alpha V \beta 6$, appear to contribute to the metastatic process of CRCs $[12,13]$. Interestingly, the $\beta 6$ subunit is expressed at very low levels in epithelia under normal conditions but is detected in both CRC primary tumours and metastasis where it acts through various mechanisms and systems to promote cancer progression [12]. However, there are exceptions. For instance, $\alpha 8 \beta 1$ which has also been shown to promote intestinal cell migration and proliferation in normal cells [14] appears to be no longer expressed by CRC cells [15]. Further investigation using normal intestinal cells revealed that this integrin acts as an anoikis-sensitizing trigger factor while the repression of its expression abolished this checkpoint [15]. Conversely, its reintroduction into CRC cells restores sensitivity to anoikis [15]. The $\alpha \mathrm{V} \beta 3$ integrin was also reported to act as an anoikis-sensitizing integrin for CRC cells [16,17]. These examples illustrate the crucial importance of the integrins as extracellular matrix molecule receptors involved in CRC cell progression, some susceptible to directly act in its promotion such as $\alpha 1 \beta 1, \alpha 5 \beta 1$ and $\alpha \mathrm{V} \beta 6$ while others act as preventive checkpoints such as $\alpha 8 \beta 1$ and $\alpha \mathrm{V} \beta 3$ or favour quiescence and differentiation rather than proliferation such as $\alpha 3 \beta 1$ and $\alpha 7 \beta 1$. These effects are also context-dependent over the entire process, some acting at early stages of cancer development while, as mentioned above, others are more likely to act at a later stage such as in the metastatic process. Some integrins likely exert dual promoting/suppressive influence on CRC development and progression [18]. In this context, integrin $\alpha 6 \beta 4$ is one of the most intriguing cases since its different role in CRC may in part derive from it ability to assemble hemidesmosomes, a very stable cell-extracellular matrix adhesion structure, and its potential to modulate oncogenic cell signalling events when released from hemidesmosomes as well as its $\alpha 6 \mathrm{~A} / \alpha 6 \mathrm{~B}$ variant composition. While it belongs to the laminin-binding integrin subset, which also includes $\alpha 3 \beta 1, \alpha 6 \beta 1$ and $\alpha 7 \beta 1[2,19,20], \alpha 6 \beta 4$ is characterized by a large $\beta$ subunit and its 
predominant expression is in parenchymal cells such as the epithelial cells that line the luminal surface of the colonic crypts.

In this review, I will first present studies reporting increased expression of the $\beta 4$ integrin subunit in CRC lesions and potential mechanisms accounting for the regulation of its expression. Through its unusual long cytoplasmic domain, the $\beta 4$ subunit is also subject to relatively complex inside out and outside in signalling regulation that can affect both cellular adhesion and migration. $\beta 4$ can only dimerize with the $\alpha 6$ subunit. In epithelial cells, this association appears exclusive since most $\alpha 6$, if not all, is associated with $\beta 4$. The $\alpha 6$ subunit is subject to alternative splicing, generating two potential variants called $\alpha 6 \mathrm{~A}$ and $\alpha 6 \mathrm{~B}$. In contrast to other tissues that predominantly express one or the other, the two variants are expressed in the epithelium of the small and large intestines but in distinct compartments, $\alpha 6 \mathrm{~B}$ being restricted to the quiescent differentiated cells while $\alpha 6 \mathrm{~A}$ is predominant in the normal proliferative cells required for the renewal of the digestive epithelium as well as in cancer cells. Progress concerning the mechanisms leading to $\alpha 6 \mathrm{~A}$ (ITGA6A) expression in neoplastic cells and its role in CRC progression will also be presented. Finally, as expected from these data, ITGA6A and ITGB4 expressions in CRC primary tumours have been explored as prognostic factors; 1 will also present rationale for using ITGA6 variants as biomarkers and data that confirm their validity for identifying patients with CRC lesions in a non-invasive mRNA-based stool test.

Please note that as per convention, we are using the $\alpha 6 / \beta 4$ denomination for the proteins and ITGA6/ITGB4 for the genes/transcripts.

\section{2. $\beta 4$ Integrin Subunit (ITGB4) in CRC}

\subsection{Expression}

The expression of the integrin $\beta 4$ subunit in CRC has been the subject of a number of studies. While most of these have shown that $\beta 4$ is uniformly distributed at the basal side of the colonic epithelium, its level of expression in primary CRC tumours was initially found to be quite variable depending on the study and antibody used, being found to be reduced or lost [21], maintained [22] or increased $[23,24]$. Increased expression was finally confirmed using a panel of distinct anti- $\beta 4$ antibodies and validated at the transcript level [25].

The use of this panel of anti- $\beta 4$ antibodies including two directed against extracellular epitopes and two targeting the cytoplasmic $\mathrm{COOH}$-domain revealed interesting features. Indeed, in the normal small intestine and colon, cells of the crypts expressed a co-translationally processed form of $\beta 4$ lacking the cytoplasmic terminal domain ( $\beta 4$ ctd-) [26] so that only antibodies directed to the extracellular domain stained epithelial cells of the colonic crypts [25]. In contrast, the differentiated cells of the small intestinal villi and colonic surface epithelium expressed normal $\beta 4 c t d+$ suggesting that the $\beta 4$ ctd-form is related to the proliferative and less differentiated cells of the renewing intestinal epithelium $[25,26]$. Unexpectedly, colonic cells from both primary CRC and established adenocarcinoma cell lines expressed the $\beta 4 \mathrm{ctd}+$ form, suggesting that this processing of $\beta 4$ is lost or at least downregulated in neoplastic cells [25]. The potential impact of this is addressed below.

\subsection{Regulation of Expression}

Integrin $\beta 4$ subunit expression appears to be mainly regulated at the transcript level but the mechanism of its overexpression in CRC cells is still incompletely understood. There have been a number of studies that have reported specific potential interactions of transcription factors with the ITGB4 promoter since its cloning [27] in a variety of cell types including RUNX1 [28], JUN [29] and KLF4 [30]. In CRC cells, MYC was the first transcription factor identified that promotes ITGB4 transcription [25] but recent studies have found others such as ZKSCAN3 [31] and FOSL1 [32] that need to be considered. Epigenetic regulation of ITGB4 expression has also been suggested after identification of microRNAs that may target the ITGB4 transcript such as miR-21 [33] and miR-335-5p [32] as well as hypomethylation of the ITGB4 promoter [32]. 


\subsection{Change in Functionality}

In normal epithelial cells, the $\beta 4$ subunit is one of the key components of hemidesmosomes, a specialized adhesive structure found in epithelia. Most integrin $\beta$ subunits bear short cytoplasmic domains smaller than 50 amino acids able to interact with actin filaments through cytoplasmic linker proteins such as talin and vinculin that are also used as scaffolding for the recruitment and activation of intracellular signalling pathways [34]. In contrast, $\beta 4$ has a 1000 amino acid cytoplasmic domain composed of distinct sequences not found in other $\beta$ integrins: a Calx $\beta$ motif adjacent to the plasma membrane, two pairs of fibronectin type III domains, a connecting segment and a $\mathrm{COOH}$-terminal end domain [35]. In hemidesmosomes, $\alpha 6 \beta 4$ mediates the intracellular interaction with cytoskeletal keratins through various plakins such as plectin and the extracellular interaction with laminins, preferentially laminin-332 [35]. However, hemidesmosomes are dynamic structures that need to be dismantled to allow cell migration and other cell dynamic functions. There are a number of mechanisms that have been suggested for the release of $\alpha 6 \beta 4$ from the hemidesmosomes [18] mainly the phosphorylation of the $\beta 4$ cytoplasmic tail in response to receptor tyrosine kinase activation by growth factors $[18,36]$. Upon release, $\alpha 6 \beta 4$ switches its association with cytokeratin to relocalize with actin filaments favouring the formation of motility structures [36]. In this context, it is worth mentioning that the processing of $\beta 4$ into $\beta 4$ ctd- in normal proliferating intestinal cells impairs the ability of $\alpha 6 \beta 4$ to bind to laminin [26], which by increasing susceptibility to anoikis may represent an additional checkpoint mechanism for preventing aberrations in the permanent cell population responsible for epithelial renewal in the intestine [37].

In carcinoma cells, numerous studies have demonstrated that $\alpha 6 \beta 4$ promotes cell motility and invasive behaviour rather than stable anchoring to the extracellular matrix via a mechanism related to the one used for cell migration in wound healing in normal cells [36]. Since the discovery that $\alpha 6 \beta 4$ promotes colonic carcinoma cell invasiveness by activating the PI3K pathway [38], there have been a number of studies that have contributed to better documenting the potential of integrin $\alpha 6 \beta 4$ to regulate multiple signal transduction cascades involved in the promotion of cell proliferation, migration, invasion and suppression of anoikis [18,36,39]. While I invite the reader to refer to these seminal reviews $[18,36,39]$ for further details about the multiple signalling transduction cascades that can be activated by $\alpha 6 \beta 4$ upon binding to its ligand, a few crucial elements are worth mentioning herein in the context of colorectal cancer (Figure 2). First, is the ability of $\alpha 6 \beta 4$ to synergistically cooperate with oncogenic receptor tyrosine kinases such as those of the epidermal growth factor receptor family and c-Met, which via their downstream effectors, the Src family of kinases, trigger the phosphorylation of tyrosine residues in the cytoplasmic domain of the $\beta 4$ subunit to enhance the signal [34]. Second are the mechanisms by which $\alpha 6 \beta 4$ promote migration and invasion, which include the activation of the small GTPase RhoA and the up-regulation of the metastasis-associated protein S-100A4 [36]. Third is the apparent dual influence of $\alpha 6 \beta 4$ on cell survival. In most cell types, cell survival requires an $\alpha 6 \beta 4$-dependent PI3K activation and blocking $\alpha 6 \beta 4$-mediated adhesion trigger apoptosis [39]. However, using the RKO colon carcinoma cell line, Mercurio's team showed that the ability of $\alpha 6 \beta 4$ to promote or inhibit apoptosis depends on the p53 cell status. Furthermore, the loss of the $\beta 4 \mathrm{ctd}$ form in carcinoma cells, which strengthens $\alpha 6 \beta 4$-laminin interactions, and thus outside-in signalling, may also account for these effects. 


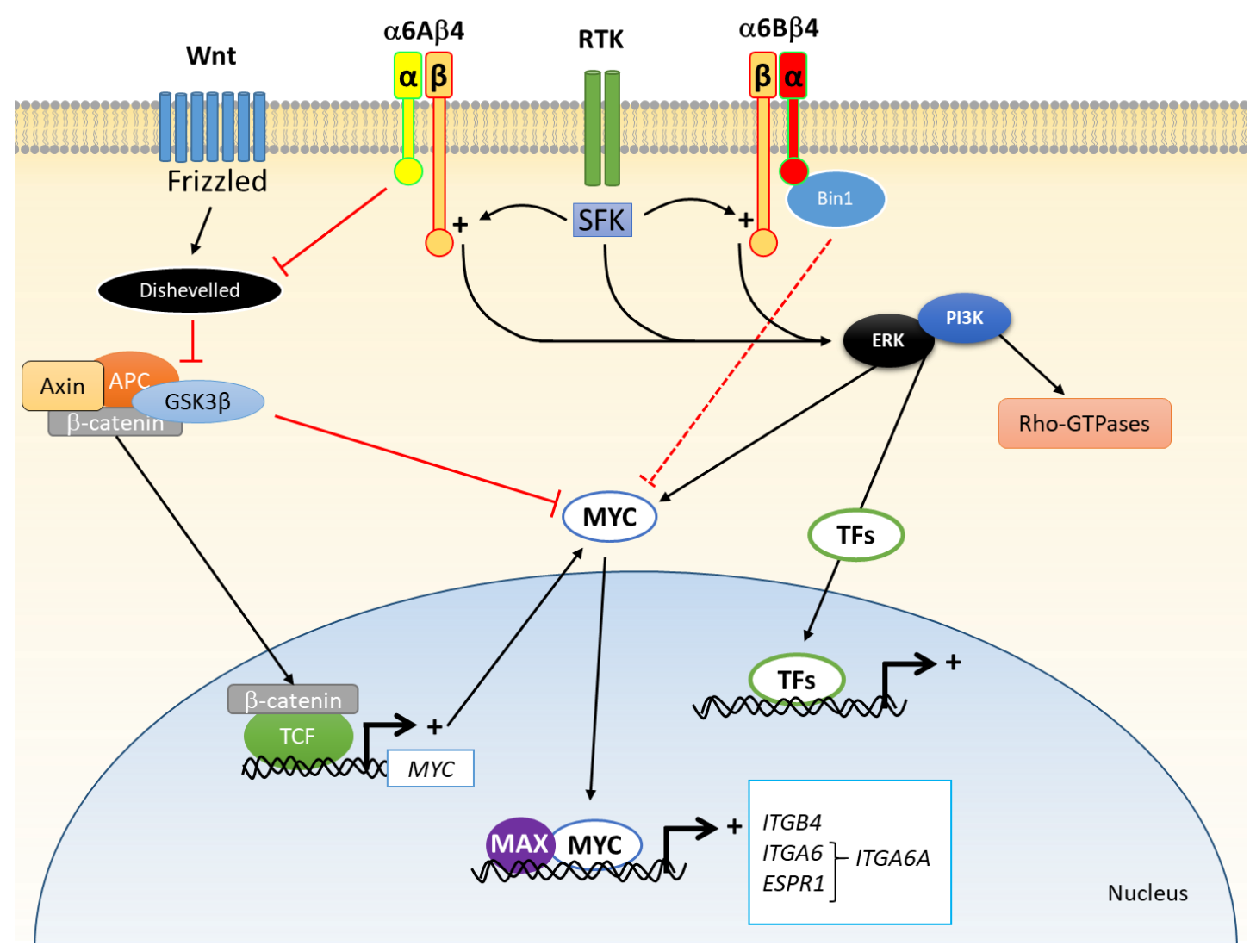

Figure 2. Some of the signaling pathways regulated by integrin $\alpha 6 \beta 4$ in colorectal cancer cells. First is the cooperation between receptor tyrosine kinases (RTK), which via Src family of kinases (SFK) trigger phosphorylation of the cytoplasmic domain of $\beta 4$ to activate the ERK and PI3K signaling pathways, which in turn regulate various cellular functions such as migration, proliferation and survival by the modulation of specific transcription factors (TFs) and activation of the Rho-GTPases. Second are the regulatory effects of the $\alpha 6$ subunit on cell proliferation where $\alpha 6 \mathrm{~A}$ promotes the $\mathrm{Wnt} / \beta$-catenin pathway and the expression of downstream effectors such as MYC while $\alpha 6 \mathrm{~B}$ appears to inhibit MYC activity by a possible interaction with the protein bridging integrator 1 (Bin1). MYC appears also as one key regulator of integrin expression since both ITGB4 and ITGA6 have MYC-responsive elements in their promoters as for ESPR1 that encodes a splicing factor that regulate ITGA6A expression. Adapted from $[18,36,39,40]$.

\section{3. $\alpha 6$ Integrin Subunit (ITGA6) in CRC}

\subsection{Expression}

As mentioned above, the integrin $\alpha 6$ subunit is the only possible dimerization partner for $\beta 4$. ITGA6, as for ITGA3 and ITGA7 thought to have been derived from a common ancestor [20], is subject to alternative splicing of its exon 25 , leading to the generation of two variants of the $\alpha 6$ subunits, $\alpha 6 \mathrm{~A}$ and $\alpha 6 \mathrm{~B}$, that are distinct in their unique cytoplasmic sequences [20]. Although the $\alpha 6$ variants were reported and characterized more than 25 years ago and are likely to participate in distinct signalling cascades [41], the relationship between variant expression and distinctive cell functions has remained elusive especially in tumorigenesis [18].

As for many other epithelial cell types, intestinal cells can express both variants [41]. Closer analysis of $\alpha 6 \mathrm{~A}$ and $\alpha 6 \mathrm{~B}$ distribution in the intact normal human gut with a panel of anti- $\alpha 6$ antibodies revealed that $\alpha 6 \mathrm{~A}$ was predominantly detected in the proliferative cells of the small and large intestine while the $\alpha 6 \mathrm{~B}$ subunit was more restricted to the quiescent/differentiated cells lying on the villus and surface epithelium of the two intestinal segments [42,43]. Predominant expression of $\alpha 6 \mathrm{~A}$ in 
proliferative/undifferentiated cells and its gradual replacement by the $\alpha 6 \mathrm{~B}$ subunit in differentiating cells has also been confirmed in intestinal cell models [43].

Expression of the $\alpha 6$ variants was investigated in CRC in situ and in adenocarcinoma cell lines. In CRC primary tumours, although most carcinoma cells expressing both $\alpha 6 \mathrm{~A}$ and $\alpha 6 \mathrm{~B}$ a clear loss of $\alpha 6 \mathrm{~A} / \alpha 6 \mathrm{~B}$ segregation was observed [43]. Quantitatively, a clear increase in total ITGA6 transcripts was noted in CRC as compared to the corresponding resection margins and this increase was attributed to an up-regulation in ITGA6A expression, with total levels of ITGA6B remaining comparable to those of the resection margins [44]. Consistently, all colorectal adenocarcinoma cell lines tested under proliferative conditions showed predominant ITGA6A expression.

\subsection{Regulation of Expression}

Information about transcriptional regulation of ITGA6 expression is still limited. Among the consensus binding sites for the transcription factors SP1, NF-kB, AP1 and MYC identified on the ITGA6 promoter [45], only SP1/SP3 have been confirmed [46]. Considering the fact that MYC expression is up-regulated in a large proportion of CRC $[47,48]$ and that data indicating that MYC controls the expression of many genes in CRC cells including several key integrin subunits [40], which comprise ITGB4 [25], MYC represents a potential regulator of ITGA6 transcription. Pharmacological inhibition of MYC activity as well as molecular manipulations of intracellular MYC levels has shown a direct concordance between MYC levels and ITGA6 expression in intestinal cells while chromatin immunoprecipitation assays have confirmed the functionality of the MYC binding site on the ITGA6 promoter in the intestinal context [49].

Since neo ITGA6 is expressed under the form of ITGA6A in CRC cells [24], the mechanism responsible for the up-regulation of this spliced form was further investigated. Alternative splicing of ITGA6 has been relatively well studied and at least 10 splicing factors have been identified under various contexts but not in CRC cells. Among the various factors tested, the epithelial splicing regulatory protein 2 (ESPR2) was identified to be the main splicing factor responsible for ITGA6A expression in CRC cells [49]. It is noteworthy that ESPR1 was found to be responsible for ITGA6 splicing in breast cancer cells [50] but in contrast to ESPR2 that was found to be up-regulated by MYC, ESPR1 was not modulated in CRC cells by this factor [49]. Further identification of MYC as a direct activator of ESPR2 active transcription indicates that MYC regulates both ITGA6 and ESPR2 expression resulting in the specific up regulation of ITGA6A in CRC cells [30].

\subsection{Change in Functionality}

It is interesting to note that the cells of the crypt proliferative compartment, which predominantly express $\alpha 6 \mathrm{~A} / \mathrm{ITGA6A}$ [42,43], are also the cells that express MYC in the normal colon [9]. Experimental studies using a normal intestinal epithelial crypt cell line showed that MYC regulates ITGA6A expression [49]. These data suggest that the MYC-dependent regulation of ITGA6A is a phenomenon occurring in the normal intestine, which appears to be exploited throughout the neoplastic process.

Indeed, colorectal cancer cell lines express 5-10 times more ITGA6A and MYC that their normal counterparts [49] while the integrin $\alpha 6 \mathrm{~A} \beta 4$ was found to promote proliferation in colorectal cancer cells [44]. Specific knockdown expression of ITGA6A in various CRC cell lines was also accompanied by a reduction in the capacity of these cells to develop tumours [44]. Incidentally, the ability of $\alpha 6 \mathrm{~A} \beta 4$ to promote proliferation in cancer cells was found to be mediated by activation of the $\mathrm{Wnt} / \beta$-catenin pathway [44], a central signalling cascade required for intestinal crypt stem cell homoeostasis that is also exploited by CRC cells [51]. As MYC is a Wnt/B-catenin target gene [40], this suggests a feed forward loop for $\alpha 6 \mathrm{~A} \beta 4$ and MYC expressions responsible for the overexpression of the two molecules in cancer cells. In this context, it is worth mentioning that experimental overexpression of $\alpha 6 \mathrm{~B}$ results in the inhibition of MYC activity [43], an effect potentially mediated by the selective interaction of the MYC inhibitor nucleoshuttling scaffold protein bridging integrator 1 with the $\alpha 6 \mathrm{~B}$ cytoplasmic domain [40]. 


\section{The Integrin $\alpha 6 \beta 4$ in CRC}

In summary, while there is a clear segregation of $\alpha 6 \beta 4$ forms in the normal intestinal mucosa where $\alpha 6 \mathrm{~A} \beta 4 \mathrm{cdt}$ - is expressed by the proliferative cells of the lower crypt and $\alpha 6 \mathrm{~B} \beta 4 \mathrm{ctd}+$ is mainly expressed by the quiescent and differentiated cells of the upper crypt and surface epithelium, cancer cells predominantly overexpress $\alpha 6 \beta 4$ under the $\alpha 6 \mathrm{~A} \beta 4 \mathrm{ctd}+$ hybrid form (Figure 3), which appears to mediate both cell proliferation and suppression of anoikis [39,52].

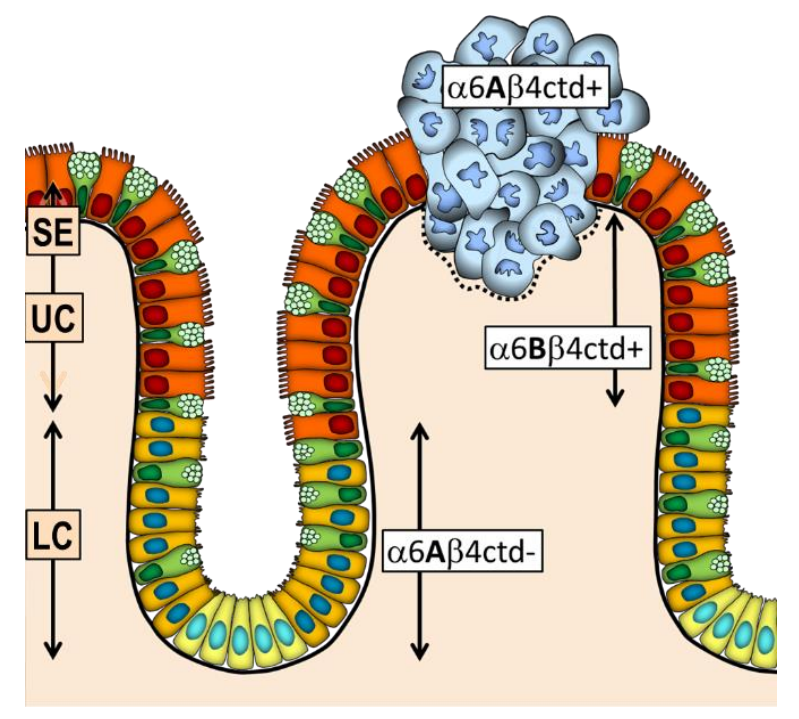

Figure 3. Integrin $\alpha 6 \beta 4$ expressed in the human colonic mucosa. In the lower crypt (LC), which contains stem cells (yellow) and proliferative absorptive and goblet cell precursors (gold and light green), $\alpha 6 \beta 4$ is expressed under the form of $\alpha 6 \mathrm{~A} \beta 4 \mathrm{ctd}$ - while in the upper crypt (UC) and surface epithelium (SE), which contains quiescent absorptive and goblet cells (orange and green), it is under the form of $\alpha 6 \mathrm{~B} \beta 4 \mathrm{ctd}+$. In carcinoma (blue), this segregation is lost and $\alpha 6 \beta 4$ is predominantly expressed under the pro-proliferative form $\alpha 6 \mathrm{~A} \beta 4 \mathrm{ctd}+$.

\section{Use of ITGA6 and ITGB4 as Biomarkers for CRC}

In light of the functional evidence described above indicating that $\alpha 6 \beta 4$ is directly involved in the various steps of CRC progression, there has been growing interest toward assessing its clinical significance as a biomarker for monitoring two critical phases of CRC development: early tumour detection and prognosis.

\subsection{Prognostic Factors}

There have been a number of studies that have investigated ITGA6 and ITGB4 expression in CRC. Based on the large public datasets that store this information as well as software that allows efficient data mining, it is becoming more and more affordable to analyze these data to compare their expression with pathological features and patient survival. In a recent study, Li et al. [32] analyzed the relation of ITGB4 level expression in tumours with overall survival using four distinct NCBI GEO datasets as well as the TCGA dataset, selected on the basis of their size (more than 50 patients) and availability of overall survival information. Using the integrated data, high expression of ITGB4 in CRC was found to be significantly associated with an unfavorable overall survival rate indicating that it is a prognostic factor for colon cancer [32]. ITGA6 has also been investigated but it was found that its expression did not influence the association of ITGB4 expression with prognosis in colorectal cancer [32]. However, the ITGA6A variant was not specifically considered making the result difficult to interpret. Incidentally, based on the use of genetically modified mouse Itga6 mutant models, De Archangelis et al. concluded that the $\alpha 6 \beta 4$ integrin could be classified as a tumour suppressor in the colon based on their observations that depletion of the $\alpha 6$ subunit in intestinal epithelial cells leads to a chronic 
inflammation that drives the subsequent development of tumors [53], albeit numerous indications that it may drive CRC progression instead, a phenomenon that may be the result of the opposite effect of $\alpha 6 \mathrm{~A}$ and $\mathrm{B}$ subunit variants on cell functions such as proliferation [54], as summarized above. Consideration of ITGA6A and ITGA6B separately in future studies should help to clarify these issues.

\subsection{Screening Factors}

Detection of CRC at early stages is a key factor for reducing mortality because this cancer can be treated with high success rates before the occurrence of metastasis [55,56]. Advanced adenomas (AA) are also important to detect since these are considered to be precursors for CRC $[57,58]$. While colonoscopy remains the gold standard for the detection of colorectal lesions (with sensitivities up to 95\% for CRC and $76 \%$ for AA), it is an invasive and relatively complex and unpleasant procedure [59]. On the other hand, the fecal immunochemical test (FIT) that detects blood (hemoglobin) in the stools has been used for some time as a non-invasive method but the relatively poor precursor lesion detection rates $(66 \%-80 \%$ sensitivity for CRC but less than $28 \%$ for AA) limits its utility $[60,61]$ and has triggered exploration of alternate strategies with the potential to improve CRC and AA screening performance. Most of these new strategies are based on non-invasive stool testing for the detection of CRC specific markers and rely on the high rate of intact tumour cells exfoliated into the colon-rectal lumen, a parameter independent of blood release [62,63].

While a number of approaches have been proposed over recent years to test released colorectal cancer cell components, mostly nucleic acid, their impact on the improvement of CRC diagnosis has been modest. For instance, the only other FDA approved CRC screening test, Cologuard (C) which combines the detection of mutations on specific DNA segments with FIT data, improves only slightly lesion detection (92\% for CRC and $42 \%$ for AA) vs. FIT alone [64]. In a recent study, Barnell et al. [65] used an enrichment protocol for the isolation of RNA from exfoliated colonocytes and high throughput analysis, attaining $45 \%$ sensitivity for the detection of AA with a panel of selected targets. Stool mRNA for colorectal lesion screening has been successfully studied over the last decade [66,67]. Considering the up regulation of ITGA6 in cancer cells, notably under its ITGA6A form, our group has also evaluated this target in the stools of patients with colorectal lesions, based on the rationale that exfoliated cancer cells express higher levels of ITGA6 and are resistant to anchorage-dependent apoptosis, increasing the likelihood of detecting it in the stools (Figure 4).

Using a relatively straightforward protocol for RNA extraction from the stools of patients with AA (24), CRC (91) and controls (60) [68], TaqMan-based quantitative polymerase chain reaction (qPCR) with human specific primers for ITGA6 and ITGA6A confirmed the usefulness and reliability of the approach [69]. Indeed, ITGA6 levels were found to be increased in stool samples of AA and CRC at all stages while receiver operating characteristic (ROC) curves revealed that ITGA6 as a single marker can predict $75 \%$ of the AA and $81 \%$ of the CRC, with a $88 \%$ specificity [69]. Comparable results were also obtained using droplet digital PCR [70]. Interestingly, increases in stool ITGA6A levels were only found in samples from patients with CRC, consistent with previous observations in primary tumours $[43,44]$. Combining multiplex qPCR to include additional targets with ITGA6 in algorithm-based analyses should strengthen this approach toward the development of a new tool for CRC screening. 
Stool detection

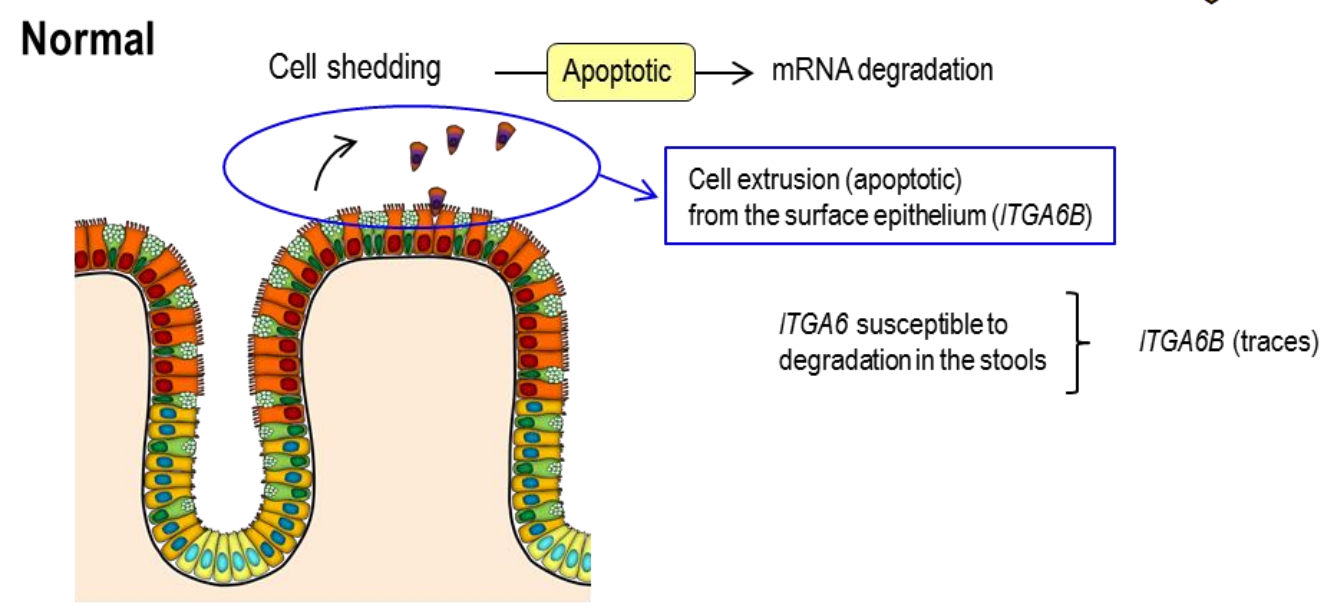

\section{CRC}

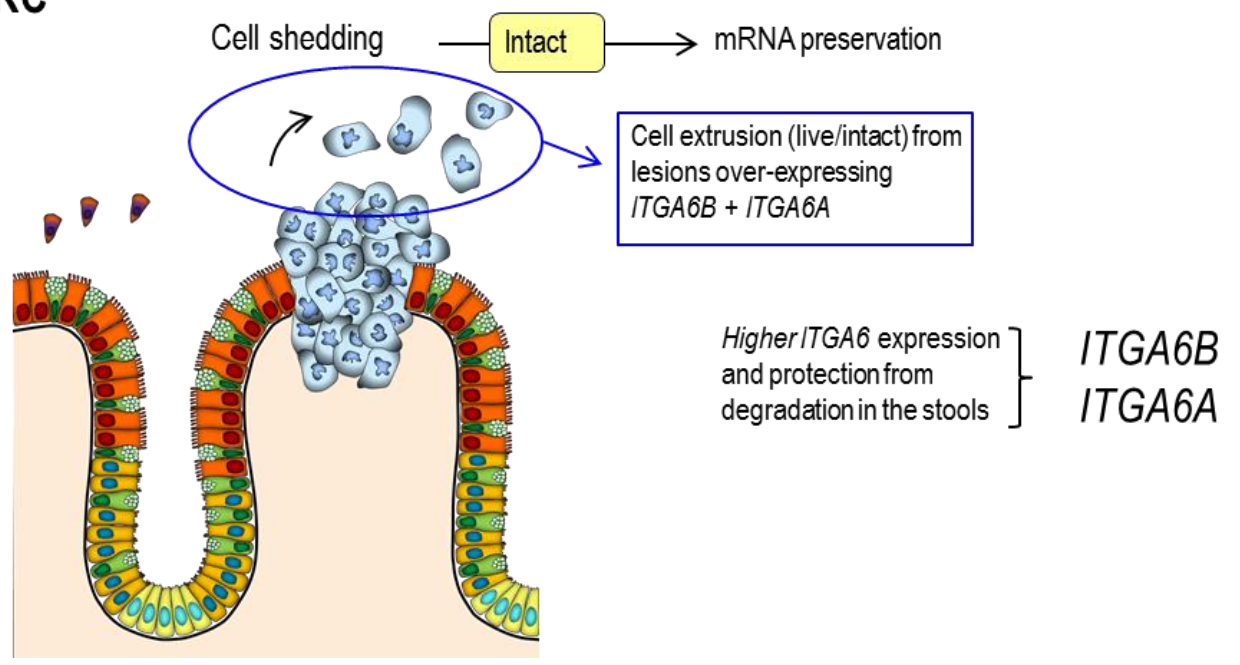

Figure 4. CRC specific markers released by tumor cells exfoliated in the stools: ITGA6. In the normal intestine, cell exfoliation is a regular process by which the oldest epithelial cells become apoptotic and are replaced by new ones produced in the lower crypt. Cell components such as nucleic acids are subject to rapid degradation resulting in a weak accumulation of intact host components in the stools. In contrast, primary tumors protruding into the lumen release a significant number of intact CRC cells that are resistant to apoptosis. Over-expressed cancer cell components such as ITGA6 are thus likely protected from degradation and can be recovered in detectable levels by standard extraction making them good biomarkers for CRC screening.

\section{Conclusions}

Since its discovery as being predominantly expressed in primary CRC, integrin $\alpha 6 \beta 4$ has been the subject of various studies that have shown that this laminin receptor can mediate pro-migratory, pro-proliferative and pro-survival properties to cancer cells, three characteristics associated with CRC progression. Incidentally, new studies have shown that ITGA6 and ITGB4 have clinical relevance as biomarkers for a stool-based non-invasive CRC screening test and as indicators of overall survival, respectively. Further studies should contribute to implementing these data in the clinical care area, ITGA6 and ITGB4 representing potential therapeutic targets as well as biomarkers for assessing therapeutic therapies. 
Funding: The work presented was supported by grants from the Canadian Institutes of Health Research (MOP-97836, MOP-123415, PPP-133373). The author was the recipient of the Canada Research Chair in Intestinal Physiopathology.

Acknowledgments: I wish to thank the members of my laboratory for discussions, namely Nuria Basora, David Gagné, Anders Bondo Dydensborg, Hehong Ni, Salah Boudjadi, Jean-François Groulx and Pierre H.Vachon who were involved in the original work on $\alpha 6 \beta 4$ in cancer cells as well as Elizabeth Herring, Shigeru Kanaoka and Eric Tremblay who were involved in the stool mRNA assay for colorectal lesion detection. I also thank Elizabeth Herring for revising the manuscript.

Conflicts of Interest: The authors declare no conflict of interest.

\section{References}

1. Cloutier, G.; Sallenbach-Morrissette, A.; Beaulieu, J.F. Non-integrin laminin receptors in epithelia. Tissue Cell 2019, 56, 71-78. [CrossRef]

2. Beaulieu, J.F. Integrins and human intestinal cell functions. Front. Biosci. 1999, 4, 310-321. [CrossRef]

3. Beaulieu, J.F. Extracellular matrix components and integrins in relationship to human intestinal epithelial cell differentiation. Prog. Histochem. Cytochem. 1997, 31, 1-76. [CrossRef]

4. Humphries, J.D.; Chastney, M.R.; Askari, J.A.; Humphries, M.J. Signal transduction via integrin adhesion complexes. Curr. Opin. Cell Biol. 2019, 56, 14-21. [CrossRef] [PubMed]

5. Kechagia, J.Z.; Ivaska, J.; Roca-Cusachs, P. Integrins as biomechanical sensors of the microenvironment. Nat. Rev. Mol. Cell Biol. 2019, 20, 457-473. [CrossRef] [PubMed]

6. Hussey, G.S.; Keane, T.J.; Badylak, S.F. The extracellular matrix of the gastrointestinal tract: A regenerative medicine platform. Nat. Rev. Gastroenterol. Hepatol. 2017, 14, 540-552. [CrossRef] [PubMed]

7. Boudjadi, S.; Carrier, J.C.; Beaulieu, J.F. Integrin alpha1 subunit is up-regulated in colorectal cancer. Biomark. Res. 2013, 1, 16. [CrossRef]

8. Boudjadi, S.; Carrier, J.C.; Groulx, J.F.; Beaulieu, J.F. Integrin alpha1beta1 expression is controlled by c-MYC in colorectal cancer cells. Oncogene 2016, 35, 1671-1678. [CrossRef]

9. Boudjadi, S.; Bernatchez, G.; Senicourt, B.; Beausejour, M.; Vachon, P.H.; Carrier, J.C.; Beaulieu, J.F. Involvement of the Integrin alpha1beta1 in the Progression of Colorectal Cancer. Cancers 2017, 9, 96. [CrossRef]

10. Basora, N.; Desloges, N.; Chang, Q.; Bouatrouss, Y.; Gosselin, J.; Poisson, J.; Sheppard, D.; Beaulieu, J.F. Expression of the alpha9beta1 integrin in human colonic epithelial cells: Resurgence of the fetal phenotype in a subset of colon cancers and adenocarcinoma cell lines. Int. J. Cancer 1998, 75, 738-743. [CrossRef]

11. Desloges, N.; Basora, N.; Perreault, N.; Bouatrouss, Y.; Sheppard, D.; Beaulieu, J.F. Regulated expression of the integrin alpha9beta1 in the epithelium of the developing human gut and in intestinal cell lines: Relation with cell proliferation. J. Cell. Biochem. 1998, 71, 536-545. [CrossRef]

12. Cantor, D.I.; Cheruku, H.R.; Nice, E.C.; Baker, M.S. Integrin alphavbeta6 sets the stage for colorectal cancer metastasis. Cancer Metastasis Rev. 2015, 34, 715-734. [CrossRef] [PubMed]

13. Pelillo, C.; Bergamo, A.; Mollica, H.; Bestagno, M.; Sava, G. Colorectal Cancer Metastases Settle in the Hepatic Microenvironment Through alpha5beta1 Integrin. J. Cell. Biochem. 2015, 116, 2385-2396. [CrossRef] [PubMed]

14. Benoit, Y.D.; Lussier, C.; Ducharme, P.A.; Sivret, S.; Schnapp, L.M.; Basora, N.; Beaulieu, J.F. Integrin alpha8beta1 regulates adhesion, migration and proliferation of human intestinal crypt cells via a predominant RhoA/ROCK-dependent mechanism. Biol. Cell 2009, 101, 695-708. [CrossRef] [PubMed]

15. Benoit, Y.D.; Larrivee, J.F.; Groulx, J.F.; Stankova, J.; Vachon, P.H.; Beaulieu, J.F. Integrin alpha8beta1 confers anoikis susceptibility to human intestinal epithelial crypt cells. Biochem. Biophys. Res. Commun. 2010, 399, 434-439. [CrossRef] [PubMed]

16. Kozlova, N.I.; Morozevich, G.E.; Chubukina, A.N.; Berman, A.E. Integrin alphavbeta3 promotes anchorage-dependent apoptosis in human intestinal carcinoma cells. Oncogene 2001, 20, 4710-4717. [CrossRef] [PubMed]

17. Morozevich, G.E.; Kozlova, N.I.; Chubukina, A.N.; Berman, A.E. Role of integrin alphavbeta3 in substrate-dependent apoptosis of human intestinal carcinoma cells. Biochemistry (Moscow) 2003, 68, 416-423. [CrossRef]

18. Ramovs, V.; Te Molder, L.; Sonnenberg, A. The opposing roles of laminin-binding integrins in cancer. Matrix Biol. 2017, 57-58, 213-243. [CrossRef] 
19. Pouliot, N.; Kusuma, N. Laminin-511: A multi-functional adhesion protein regulating cell migration, tumor invasion and metastasis. Cell Adhes. Migr. 2013, 7, 142-149. [CrossRef]

20. de Melker, A.A.; Sonnenberg, A. Integrins: Alternative splicing as a mechanism to regulate ligand binding and integrin signaling events. Bioessays 1999, 21, 499-509. [CrossRef]

21. Stallmach, A.; von Lampe, B.; Matthes, H.; Bornhoft, G.; Riecken, E.O. Diminished expression of integrin adhesion molecules on human colonic epithelial cells during the benign to malign tumour transformation. Gut 1992, 33, 342-346. [CrossRef] [PubMed]

22. Lohi, J.; Oivula, J.; Kivilaakso, E.; Kiviluoto, T.; Frojdman, K.; Yamada, Y.; Burgeson, R.E.; Leivo, I.; Virtanen, I. Basement membrane laminin-5 is deposited in colorectal adenomas and carcinomas and serves as a ligand for alpha3beta1 integrin. Apmis 2000, 108, 161-172. [CrossRef] [PubMed]

23. Falcioni, R.; Turchi, V.; Vitullo, P.; Navarra, G.; Ficari, F.; Cavaliere, F.; Sacchi, A.; Marianicostantini, R. Integrin beta-4 expression in colorectal-cancer. Int. J. Oncol. 1994, 5, 573-578. [CrossRef] [PubMed]

24. Sordat, I.; Bosman, F.T.; Dorta, G.; Rousselle, P.; Aberdam, D.; Blum, A.L.; Sordat, B. Differential expression of laminin-5 subunits and integrin receptors in human colorectal neoplasia. J. Pathol. 1998, 185, 44-52. [CrossRef]

25. Ni, H.; Dydensborg, A.B.; Herring, F.E.; Basora, N.; Gagne, D.; Vachon, P.H.; Beaulieu, J.F. Upregulation of a functional form of the beta4 integrin subunit in colorectal cancers correlates with c-Myc expression. Oncogene 2005, 24, 6820-6829. [CrossRef] [PubMed]

26. Basora, N.; Herring-Gillam, F.E.; Boudreau, F.; Perreault, N.; Pageot, L.P.; Simoneau, M.; Bouatrouss, Y.; Beaulieu, J.F. Expression of functionally distinct variants of the beta4A integrin subunit in relation to the differentiation state in human intestinal cells. J. Biol. Chem. 1999, 274, 29819-29825. [CrossRef] [PubMed]

27. Takaoka, A.S.; Yamada, T.; Gotoh, M.; Kanai, Y.; Imai, K.; Hirohashi, S. Cloning and characterization of the human beta4-integrin gene promoter and enhancers. J. Biol. Chem. 1998, 273, 33848-33855. [CrossRef]

28. Phillips, J.L.; Taberlay, P.C.; Woodworth, A.M.; Hardy, K.; Brettingham-Moore, K.H.; Dickinson, J.L.; Holloway, A.F. Distinct mechanisms of regulation of the ITGA6 and ITGB4 genes by RUNX1 in myeloid cells. J. Cell. Physiol. 2018, 233, 3439-3453. [CrossRef]

29. An, X.Z.; Zhao, Z.G.; Luo, Y.X.; Zhang, R.; Tang, X.Q.; Hao, D.; Zhao, X.; Lv, X.; Liu, D. Netrin-1 suppresses the MEK/ERK pathway and ITGB4 in pancreatic cancer. Oncotarget 2016, 7, 24719-24733. [CrossRef]

30. Ma, B.; Zhang, L.; Zou, Y.; He, R.; Wu, Q.; Han, C.; Zhang, B. Reciprocal regulation of integrin beta4 and KLF4 promotes gliomagenesis through maintaining cancer stem cell traits. J. Exp. Clin. Cancer Res. 2019, 38, 23. [CrossRef]

31. Yang, L.; Zhang, L.; Wu, Q.; Boyd, D.D. Unbiased screening for transcriptional targets of ZKSCAN3 identifies integrin beta 4 and vascular endothelial growth factor as downstream targets. J. Biol. Chem. 2008, 283, 35295-35304. [CrossRef] [PubMed]

32. Li, M.; Jiang, X.; Wang, G.; Zhai, C.; Liu, Y.; Li, H.; Zhang, Y.; Yu, W.; Zhao, Z. ITGB4 is a novel prognostic factor in colon cancer. J. Cancer 2019, 10, 5223-5233. [CrossRef] [PubMed]

33. Ferraro, A.; Kontos, C.K.; Boni, T.; Bantounas, I.; Siakouli, D.; Kosmidou, V.; Vlassi, M.; Spyridakis, Y.; Tsipras, I.; Zografos, G.; et al. Epigenetic regulation of miR-21 in colorectal cancer: ITGB4 as a novel miR-21 target and a three-gene network (miR-21-ITGBeta4-PDCD4) as predictor of metastatic tumor potential. Epigenetics 2014, 9, 129-141. [CrossRef] [PubMed]

34. Cooper, J.; Giancotti, F.G. Integrin Signaling in Cancer: Mechanotransduction, Stemness, Epithelial Plasticity, and Therapeutic Resistance. Cancer Cell 2019, 35, 347-367. [CrossRef] [PubMed]

35. Walko, G.; Castanon, M.J.; Wiche, G. Molecular architecture and function of the hemidesmosome. Cell Tissue Res. 2015, 360, 529-544. [CrossRef]

36. Stewart, R.L.; O'Connor, K.L. Clinical significance of the integrin alpha6beta4 in human malignancies. Lab. Investig. 2015, 95, 976-986. [CrossRef]

37. Benoit, Y.D.; Groulx, J.F.; Gagne, D.; Beaulieu, J.F. RGD-Dependent Epithelial Cell-Matrix Interactions in the Human Intestinal Crypt. J. Signal Transduct. 2012, 2012. [CrossRef]

38. Shaw, L.M.; Rabinovitz, I.; Wang, H.H.; Toker, A.; Mercurio, A.M. Activation of phosphoinositide 3-OH kinase by the alpha6beta4 integrin promotes carcinoma invasion. Cell 1997, 91, 949-960. [CrossRef]

39. Beausejour, M.; Boutin, A.; Vachon, P.H. Anoikis regulation-Complexities, distinction, and cell differentiation. In Apoptosis and Beyond: The Many Ways Cells Die; Radosevich, J.A., Ed.; Wiley: Hoboken, NJ, USA, 2017; pp. 145-182. 
40. Boudjadi, S.; Beaulieu, J.F. MYC and integrins interplay in colorectal cancer. Oncoscience 2016, 3, 50-51. [CrossRef]

41. Hogervorst, F.; Admiraal, L.G.; Niessen, C.; Kuikman, I.; Janssen, H.; Daams, H.; Sonnenberg, A. Biochemical characterization and tissue distribution of the A and B variants of the integrin alpha 6 subunit. J. Cell. Biol. 1993, 121, 179-191. [CrossRef]

42. Dydensborg, A.B.; Teller, I.C.; Basora, N.; Groulx, J.F.; Auclair, J.; Francoeur, C.; Escaffit, F.; Pare, F.; Herring, E.; Menard, D.; et al. Differential expression of the integrins alpha6Abeta4 and alpha6Bbeta4 along the crypt-villus axis in the human small intestine. Histochem. Cell Biol. 2009, 131, 531-536. [CrossRef]

43. Dydensborg, A.B.; Teller, I.C.; Groulx, J.F.; Basora, N.; Pare, F.; Herring, E.; Gauthier, R.; Jean, D.; Beaulieu, J.F. Integrin alpha6Bbeta4 inhibits colon cancer cell proliferation and c-Myc activity. BMC Cancer 2009, 9, 223. [CrossRef] [PubMed]

44. Groulx, J.F.; Giroux, V.; Beausejour, M.; Boudjadi, S.; Basora, N.; Carrier, J.C.; Beaulieu, J.F. Integrin alpha6A splice variant regulates proliferation and the Wnt/beta-catenin pathway in human colorectal cancer cells. Carcinogenesis 2014, 35, 1217-1227. [CrossRef] [PubMed]

45. Nishida, K.; Kitazawa, R.; Mizuno, K.; Maeda, S.; Kitazawa, S. Identification of regulatory elements of human alpha 6 integrin subunit gene. Biochem. Biophys. Res. Commun. 1997, 241, 258-263. [CrossRef] [PubMed]

46. Gaudreault, M.; Vigneault, F.; Leclerc, S.; Guerin, S.L. Laminin reduces expression of the human alpha6 integrin subunit gene by altering the level of the transcription factors Sp1 and Sp3. Investig. Ophthalmol. Vis. Sci. 2007, 48, 3490-3505. [CrossRef]

47. Sikora, K.; Chan, S.; Evan, G.; Gabra, H.; Markham, N.; Stewart, J.; Watson, J. c-myc oncogene expression in colorectal cancer. Cancer 1987, 59, 1289-1295. [CrossRef]

48. Erisman, M.D.; Rothberg, P.G.; Diehl, R.E.; Morse, C.C.; Spandorfer, J.M.; Astrin, S.M. Deregulation of c-myc gene expression in human colon carcinoma is not accompanied by amplification or rearrangement of the gene. Mol. Cell. Biol. 1985, 5, 1969-1976. [CrossRef]

49. Groulx, J.F.; Boudjadi, S.; Beaulieu, J.F. MYC Regulates alpha6 Integrin Subunit Expression and Splicing Under Its Pro-Proliferative ITGA6A form in Colorectal Cancer Cells. Cancers 2018, 10, 42. [CrossRef]

50. Goel, H.L.; Gritsko, T.; Pursell, B.; Chang, C.; Shultz, L.D.; Greiner, D.L.; Norum, J.H.; Toftgard, R.; Shaw, L.M.; Mercurio, A.M. Regulated splicing of the alpha6 integrin cytoplasmic domain determines the fate of breast cancer stem cells. Cell Rep. 2014, 7, 747-761. [CrossRef]

51. Kretzschmar, K.; Clevers, H. Wnt/beta-catenin signaling in adult mammalian epithelial stem cells. Dev. Biol. 2017, 428, 273-282. [CrossRef]

52. Beaulieu, J.F. Integrin alpha6beta4 in colorectal cancer. World J. Gastrointest. Pathophysiol. 2010, 1, 3-11. [CrossRef] [PubMed]

53. De Arcangelis, A.; Hamade, H.; Alpy, F.; Normand, S.; Bruyere, E.; Lefebvre, O.; Mechine-Neuville, A.; Siebert, S.; Pfister, V.; Lepage, P.; et al. Hemidesmosome integrity protects the colon against colitis and colorectal cancer. Gut 2017, 66, 1748-1760. [CrossRef] [PubMed]

54. Beaulieu, J.F. Integrin $\alpha 6$ variants and colorectal cancer. Gut 2018, 67, 1747-1748. [CrossRef] [PubMed]

55. Robertson, D.J.; Imperiale, T.F. Stool Testing for Colorectal Cancer Screening. Gastroenterology 2015, 149, 1286-1293. [CrossRef]

56. Willyard, C. Screening: Early alert. Nature 2015, 521, S4-S5. [CrossRef]

57. Brenner, H.; Hoffmeister, M.; Stegmaier, C.; Brenner, G.; Altenhofen, L.; Haug, U. Risk of progression of advanced adenomas to colorectal cancer by age and sex: Estimates based on 840,149 screening colonoscopies. Gut 2007, 56, 1585-1589. [CrossRef]

58. Click, B.; Pinsky, P.F.; Hickey, T.; Doroudi, M.; Schoen, R.E. Association of colonoscopy adenoma findings with long-term colorectal cancer incidence. JAMA 2018, 319, 2021-2031. [CrossRef]

59. Schroy, P.C., 3rd; Lal, S.; Glick, J.T.; Robinson, P.A.; Zamor, P.; Heeren, T.C. Patient preferences for colorectal cancer screening: How does stool DNA testing fare? Am. J. Manag. Care 2007, 13, 393-400.

60. Allison, J.E.; Fraser, C.G.; Halloran, S.P.; Young, G.P. Population screening for colorectal cancer means getting FIT: The past, present, and future of colorectal cancer screening using the fecal immunochemical test for hemoglobin (FIT). Gut Liver 2014, 8, 117-130. [CrossRef]

61. Lee, J.K.; Liles, E.G.; Bent, S.; Levin, T.R.; Corley, D.A. Accuracy of fecal immunochemical tests for colorectal cancer: Systematic review and meta-analysis. Ann. Intern. Med. 2014, 160, 171. [CrossRef] 
62. Yu, Y.J.; Majumdar, A.P.; Nechvatal, J.M.; Ram, J.L.; Basson, M.D.; Heilbrun, L.K.; Kato, I. Exfoliated cells in stool: A source for reverse transcription-PCR-based analysis of biomarkers of gastrointestinal cancer. Cancer Epidemiol. Biomark. Prev. 2008, 17, 455-458. [CrossRef] [PubMed]

63. Ang, C.S.; Baker, M.S.; Nice, E.C. Mass spectrometry-based analysis for the discovery and validation of potential colorectal cancer stool biomarkers. Methods Enzymol. 2017, 586, 247-274. [CrossRef] [PubMed]

64. Imperiale, T.F.; Ransohoff, D.F.; Itzkowitz, S.H. Multitarget stool DNA testing for colorectal-cancer screening. N. Engl. J. Med. 2014, 371, 187-188. [CrossRef] [PubMed]

65. Barnell, E.K.; Kang, Y.; Wurtzler, E.M.; Griffith, M.; Chaudhuri, A.A.; Griffith, O.L.; Geneoscopy, S. Noninvasive Detection of High-Risk Adenomas Using Stool-Derived Eukaryotic RNA Sequences as Biomarkers. Gastroenterology 2019, 157, 884-887 e883. [CrossRef] [PubMed]

66. Hamaya, Y.; Yoshida, K.; Takai, T.; Ikuma, M.; Hishida, A.; Kanaoka, S. Factors that contribute to faecal cyclooxygenase-2 mRNA expression in subjects with colorectal cancer. Br. J. Cancer 2010, 102, $916-921$. [CrossRef]

67. Kanaoka, S.; Yoshida, K.; Miura, N.; Sugimura, H.; Kajimura, M. Potential usefulness of detecting cyclooxygenase 2 messenger RNA in feces for colorectal cancer screening. Gastroenterology 2004, 127, 422-427. [CrossRef]

68. Herring, E.; Kanaoka, S.; Tremblay, E.; Beaulieu, J.F. A stool multitarget mRNA assay for the detection of colorectal neoplasms. Methods Mol. Biol. 2018, 1765, 217-227. [CrossRef]

69. Beaulieu, J.F.; Herring, E.; Kanaoka, S.; Tremblay, E. Use of integrin alpha 6 transcripts in a stool mRNA assay for the detection of colorectal cancers at curable stages. Oncotarget 2016, 7, 14684-14692. [CrossRef]

70. Herring, E.; Kanaoka, S.; Tremblay, E.; Beaulieu, J.F. Droplet digital PCR for quantification of ITGA6 in a stool mRNA assay for the detection of colorectal cancers. World J. Gastroenterol. 2017, 23, 2891-2898. [CrossRef]

(C) 2019 by the author. Licensee MDPI, Basel, Switzerland. This article is an open access article distributed under the terms and conditions of the Creative Commons Attribution (CC BY) license (http://creativecommons.org/licenses/by/4.0/). 